\title{
PERFORMANCE EVALUATION OF GREEN SUPPLY CHAIN MANAGEMENT
}

\author{
POMIAR WYDAJNOŚCI ZARZĄDZANIA \\ ZIELONYMI LAŃCUCHAMI DOSTAW
}

\begin{abstract}
Streszczenie
Tylko to, co jest mierzone, może być właściwie zarządzane. Proces pomiaru powinien służyć ciągłemu doskonaleniu przedsiębiorstw i całych łańcuchów dostaw. Dane z systemu pomiaru powinny powodować wzrost współpracy i pomagać w podejmowaniu decyzji o zmianach na poziomie operacyjnym, a z drugiej strony może to być ważna informacja przy przedefinowaniu strategii. Pozwala to na rozwój łańcuchów dostaw opartych na wiedzy, gdzie zakres współpracy jest dosłownie nieograniczony (dotyczy to również aspektów ekologicznych). Istnieją dwa podstawowe podejścia do pomiaru wydajności łańcucha dostaw: kompleksowy pomiar, który patrzy na wyniki całego łańcucha (który można rozdzielić na poszczególne szczeble i poziomy), oraz pomiar częściowy, gdy mierzymy tylko niektóre aspekty. Często praktykowany jest tylko pomiar oddzielnie działających firm, a nie całego łańcucha. Problem jest jeszcze bardziej widoczny, jeśli chodzi o pomiar wydajności działań ekologicznych w zintegrowanych łańcuchach dostaw. W artykule opisano możliwości oceny wyników GSCM. Przedstawiono i oceniono główne wyzwania i przeszkody stojące przed pomiarem wyników zielonych łańcuchów dostaw.
\end{abstract}

Słowa kluczowe: Zarządzanie zielonymi łańcuchami dostaw, wydajność, model referencyjny zielonych łańcuchów dostaw, zmodyfikowana zrównoważona karta wyników

JEL clasification: L22, L29, M14, Q50

\section{Introduction}

Supply Chain Management (SCM) has been one of the most prominent management approaches both in theory and practice in recent years. Stock and Boyer define SCM as "the management of a network of relationships within a firm and between interdependent organizations and business units consisting of material suppliers, purchasing, production facilities, logistics, marketing, and related systems that facilitate the forward and reverse flow of materials,

* Katedra Marketingu i Przedsiębiorczości, Wydział Ekonomii, Uniwersytet Rzeszowski, toms@ur.edu.pl 
services, finances and information from the original producer to final customer with the benefits of adding value, maximizing profitability through efficiencies, and achieving customer satisfaction". The financial aspect is often highlighted when defining SCM. And performance measures that are usually used in supply chain performance evaluation include cost minimization, inventory minimization, buyer-supplier benefit maximization, etc. Among SC metrics cost has always been recognized as one of the most important metrics for assessing the efficiency ${ }^{2}$.

\section{The Need for Performance Evaluation}

Tracking financial results is not sufficient to measure the performance of the supply chain for the following reasons: these metrics do not provide a future perspective; they do not apply to a strategic non-financial performance, such as customer service; they are not directly linked to effectiveness and efficiency, and they do not focus on process and inter-organizational aspects ${ }^{3}$.

Companies are more and more interested in sustainability issues. Different reports show that greening of supply chains becomes a very serious trend. In one of the studies prepared by Handfield ${ }^{4}$ in 2013 more than half of surveyed companies take into consideration green issues creating their logistics strategy. In another report, only $10 \%$ of companies admit they are able to fully tackle green supply chain management practices and one of the most difficult issues is the measurement process ${ }^{5}$.

Greening seems to be more effective on the supply chain level than on the single company level because many negative environmental impacts (waste, transportation, etc.) can be eliminated or minimized by companies as a result of cooperation in sourcing, manufacturing and distributing goods. A growing interest in environmental aspects led to coining a new term - Green Supply Chain Management (GSCM). How can we define it? According to Handfield

${ }^{1}$ J.R. Stock, S.L. Boyer, Developing a consensus definition of supply chain management: a qualitative study, Int. J. Phys. Distrib. Logistics Management, 39, 2009, pp. 690-711.

2 D. Estampe, S. Lamouri, J.L. Paris, S. Brahim-Djelloul, 2013. A framework for analysing supply chain performance evaluation models, International Journal of Production Economics, Vol. 142, No. 2, 2013, pp. 247-258.

${ }^{3}$ H.J. Bullinger, M. Küchner, A. van Hoof, Analysing supply chain performance using a balanced measurement method, International Journal of Production Research 2002, Vol. 40, No. 15, p. 3539.

${ }^{4}$ R.B. Handfield, F. Straube, H.Ch. Pfohl, Trends and Strategies in Logistics and Supply Chain Management: Embracing Global Logistics Complexity to Drive Market Advantage, Hamburg 2013.

${ }^{5}$ MIT Sloan Management Review and The Boston Consulting Group 2013, Sustainability's Next Frontier, http://sloanreview.mit.edu/projects/ sustainabilitys-next-frontier 
it is "application of environmental management principles to the entire set of activities across the whole customer order cycle, including design, procurement, manufacturing and assembly, packaging, logistics, and distribution"6. Andic simply states GSCM is "minimizing and preferably eliminating the negative effects of the supply chain on the environment"7. Zhu considers GSCM "as an important new archetype for enterprises to achieve profit and market share objectives by lowering their environmental risks and impacts while raising their ecological efficiency"s.

Looking at these definitions of GSCM one can notice that apart from usually used economic performance measures it would be beneficial to try to identify the ecological aspects of performance without which it would be impossible to build green supply chain management performance system and assess effectiveness and efficiency of such actions ${ }^{9}$. It is often highlighted that for an effective green supply chain management, evaluating the overall performance of the entire chain is crucial.

\section{Importance of Information and Supply Chain Metrics for Performance Evaluation}

The important role that information management plays should be emphasized. Without it, it is impossible to integrate supply chains. Therefore, the information must be properly collected and used in decision-making on the flow of goods. Information has the following features ${ }^{10}$ :

- information technology, which allows to support logistics processes through software and hardware,

- readiness of information transfer which includes involvement in the exchange of information and available forms of exchange,

- ability to transfer information enabling information to be complete and on time, and decreasing cost of transmission.

${ }^{6}$ R.B. Handfield, S.V. Walton, L.K. Seegers, S.A. Melnyk, 'Green' value chain practices in the furniture industry, Journal of Operations Management, 15 (4), 1997, pp. 293-315.

${ }^{7}$ E. Andic, O. Yurt, T. Baltacioglu, Green supply chains: efforts and potential applications for the Turkish market. Resources, Conservation and Recycling 58, 2012, pp. 50-68.

${ }^{8}$ Q. Zhu, J. Sarkis, Y. Geng, Green supply chain management in China: pressures, practices and performance, Int. J. Operations Prod. Manag., 25, 2005, pp. 449-468.

9 A. Bhattacharya, P. Mohapatra, V. Kumar, P.K. Dey, M. Brady, M. Kumar, T. Nudurupati, S. Sai, Green supply chain performance measurement using fuzzy ANP-based balanced scorecard: a collaborative decision-making approach, Production Planning \& Control, 25 (8), 2014, pp. 698-714.

${ }^{10}$ H.Ch. Pfohl, Informationsfluss in der Logistikkette, Erich Schmidt Verlag GmbH \& Co., Berlin 1997, p. 15. 
Information management supports all areas of the company. If you strive to improve information systems and their effective use it will enhance not only the SC management, but also improve the overall functioning of the company. In practice, sharing information between members of the supply chain is the primary way to achieve improvements. The shared information should be different from the conventional exchange of information in terms of speed, quality and quantity. Successful collaboration requires modifications to the standard business practices. Sharing information contributes to better decision-making and increases the efficiency of the supply chain ${ }^{11}$. There are many obstacles to build an adequate performance measures system. The most important of them $\operatorname{are}^{12}$ : commitment of top management, integration of SC metrics with company strategy, too many indicators (often non-integrated), lack of agreed definitions of measures, mistrust and unwillingness to share information.

Companies willing to compare and use the same ste of supply chain metrics should take into consideration this step-by-step process ${ }^{13}$ :

- Determine the scope of the inquiry (e.g., planning, procurement, manufacturing, and logistics);

- Select a set of supply chain KPIs to measure and compare;

- Identify a peer group of companies; levels;

- Agree on measurements and targets that can reach the site and process

- Develop reporting templates and determine the timing of measurement (e.g., daily, weekly, etc.);

- Plan the implementation approach;

- Obtain stakeholder buy-in for benchmarking and its benefits;

- Identify tools and resources for data collection;

- Collect and validate data;

- Analyze and interpret results;

- Develop an action plan;

- Track execution of actions.

Very often single performance measures are related to single aspects of functioning of supply chains or to separate phases of supply chains such as procurement, manufacturing or distribution. Green procurement practices are related to purchasing environmentally friendly materials or the process of supplier certification concerned with environmental issues as well as environmentally

${ }^{11}$ S. Min, A.S. Roath, P.J. Daugherty, S.E. Genchev, H. Chen, A.D. Arndt, R.G. Richey, Supply chain collaboration: what's happening?, The International Journal of Logistics Management, Vol. 16, No. 2, 2005, p. 239. pp. 2-3.

${ }_{12}$ P. Dura, Mierniki procesów logistycznych, Gospodarka Materiałowa i Logistyka, 3/2002,

${ }^{13}$ V. Suri, Council Perspectives, Insights from The Conference Board Asia-Pacific Supply Chain Council, Supply Chain Benchmarking Process and Methodology, p. 22. 
friendly packaging and so on. Green manufacturing is related to product design and production processes having the lowest possible environmental impact. When thinking in terms of green manufacturing the number of components should be minimised the assembly process simplified, the usage of energy, waste and emissions should be reduced to a minimum. Green distribution is concerned with application of green thinking in planning distribution process which means trying to minimise especially transportation impact on the environment but also packaging practices. Green reverse logistics and can be understood as the process of retrieving products from customers in the way which assumes the most environmentally friendly behaviour. This can include activities such as waste collection, sorting, reprocessing or disposal. The example set of performance measurement criteria and sub-criteria is presented in Table 1.

Table 1. Green Supply Chain measurement criteria

\begin{tabular}{|c|c|c|}
\hline No. & Performance measurement criteria & Performance measurement sub-criteria \\
\hline 1 & $\begin{array}{l}\text { Green supplier partnership performance } \\
\text { (SSPP) }\end{array}$ & $\begin{array}{l}\text { 1. Cost of raw material } \\
\text { 2. Embodied carbon footprint } \\
\text { 3. Defect rate } \\
\text { 4. Flexibility rate } \\
\text { 5. Recycling rate } \\
\text { 6. Ordering cost }\end{array}$ \\
\hline 2 & Green production performance (SPDP) & $\begin{array}{l}\text { 1. Unit manufacturing cost } \\
\text { 2. Level of capacity utilization } \\
\text { 3. Energy use } \\
\text { 4. Product quality } \\
\text { 5. Production flexibility }\end{array}$ \\
\hline 3 & $\begin{array}{l}\text { Green delivery and Logistics performance } \\
\text { (SDLP) }\end{array}$ & $\begin{array}{l}\text { 1. Transportation cost } \\
\text { 2. Greenhouse gas emission } \\
\text { 3. Delivery time } \\
\text { 4. Delivery reliability }\end{array}$ \\
\hline
\end{tabular}

Source: S. K. Jakhar, Designing the Green Supply Chain Performance Optimisation Model, Global Journal of Flexible Systems Management (September 2014) 15(3), pp. 235-259, DOI 10.1007/ s40171-014-0069-6.

According to Wagner the GSC performance can be measured in terms of indexes that assess the company's environmental impact in different categories and each one can should be measured by a separate item variable ${ }^{14}$. Measures are the indicators that asses the achievement level of each performance criterion. Good

${ }^{14} \mathrm{M}$. Wagner, S. Schaltegger, The effect of corporate environmental strategy choice and environmental performance on competitiveness and economic performance: an empirical analysis of EU manufacturing, European Management Journal, 22 (5), 2004, pp. 557-572. 
metrics should (among others) ${ }^{15}$ : be well defined, be easily measurable and easy to understand, provide incentives for proper actions, be multi-dimensional and increase the confidence of partners. According to Cai "since many measurement systems lacked strategy alignment, a balanced approach and systemic thinking, they had difficulty in systematically identifying the most appropriate metrics"16.

\section{GSCM Performance Measurement System}

There are different ways of classifications of measures for evaluating the performance of supply chain. There is no widely accepted unified classification and these measures are grouped according to different characteristics, such as ${ }^{17}$ : whether they are qualitative or quantitative, what they measure: cost and non-cost, coordination efficiency and configuration, their strategic, operational or tactical focus, the process in the supply chain they relate to. Different authors point out weaknesses and discrepancies of performance measurement systems and usually they include the following ones ${ }^{18}$ : lack of connection with strategy, focus on cost, lack of a balanced approach, insufficient focus on customers and competitors, loss of supply chain context, thus encouraging local optimization, and lack of system thinking. Most of these weaknesses apply also to GSCM. The topic is new and for many companies not clearly defined, hence lack of shared and widely accepted performance measurement systems. There is not many research focusing directly on GSCM performance measurement. And the existing research show many approaches for measuring GSCM. There is no common understanding of what should be measured. This may also be due to lack of agreement on the definition of GSCM.

Here is a list of nine most important difficulties in developing performance measures ${ }^{19}$ :

- Although there is no shortage of environmental indicators, there is a difficulty in deciding on which ones to use, when and how,

- Different supply chain players must agree on which metrics to use and with which data,

${ }^{15}$ Keeping Score: Measuring the Business Value of Logistics in the Supply Chain, ed. J.S. Keebler, CSC University of Tennessee, Council of Logistics Management 1999, p. 8.

${ }^{16}$ J. Cai, X. Liu, Z. Xiao, J. Liu, 2009, Improving supply chain performance management: A systematic approach to analyzing iterative KPI accomplishment, Decision Support Systems, 46, 2009, pp. 512-521.

17 S. Mandal, Supply Chain Performance: Review of Empirical Literature, Romanian Review of Social Sciences, No. 3, 2012, pp. 26-27.

18 Ibidem.

19 E. Hassini, C. Surti, C. Searcy, A literature review and a case study of sustainable supply chains with a focus on metrics, Int. J. Production Economics 140, 2012, pp. 69-82. 
- Incompatibility between classical production measures, which are designed for intra-organizational management, and supply chain measures that should have an inter-organizational scope,

- Lack of an oversight agency that controls the whole supply chain,

- Lack of trust in the relationship and fear that data confidentiality may be compromised,

- Difficulties in aligning strategies throughout the supply chain,

- Difficulties in coordination of competencies,

- Difficulty in streamlining the different types of supply chain parties,

- Dynamic nature of supply chains.

The frameworks provided specifically for GSCM performance assessment are the ISO 14032, Green Supply Chain Operations Rreference (Green SCOR) model, and the modified Balanced Scorecard (Green BSC).

Hervani proposed ISO 14032 as a basis for green supply chain performance management system. But it should be noted that the ISO guidelines are meant for individual organizations. ${ }^{20}$ This is why it should not be considered as a holistic performance measurement system. It does not encompass the whole supply chain. Yet it can serve as a very good starting point for companies considering analysing their green performance.

Balanced Scorecard seeks to combine short-term financial perspective with those elements of the organization that do not have a financial nature, and determine the future development and prosperity of the company. The original Balanced Scorecardd proposed by Kaplan and Norton also focuses on a single company. But Ackermann modified balanced scorecard in order to adapt it to supply chain management. His proposal is also made up of four perspectives ${ }^{21:}$

- financial perspective: cash-to-cash cycle is a key indicator because it measures the effectiveness and efficiency of products and information flows between partners in the supply chain,

- customer perspective: the proposed measures include the number of points of contact with customers, relative response time and customer value ratio,

- process perspective: optimization processes within the organization needs to be extended to the entire supply chain. Metrics of internal processes include supply chain cycle,

- growth and learning perspective: the suggested metrics include the number of shared data sets and point of product finalization.

${ }^{20}$ A.A. Hervani, M.M. Helms, J. Sarkis, Performance measurement for green supply chain management, Benchmarking: An International Journal 12 (4), 2005, pp. 330-353.

${ }^{21}$ I. Ackermann, Using the balanced scorecard for supply chain management: Prerequisites, integration issues, and performance measures, [in:] Strategy and organization in supply chains, ed. S. Seuring, M. Muller, M. Goldbach, U. Schneidewind, Physica-Verlag, New York 2003, pp. 289-304. 
In response to the challenges of measuring the performance of supply chains Khoo proposed his version of Supply Chain Scorecard. It consists of four categories of measurement: ${ }^{22}$

- synchronization metrics (eg. "bullwhip effect" metrics)

- reactivity metrics (inventory cycles in the pipeline)

- reliability metrics (number of deficiencies)

- cost metrics (cost of transport and overall inventory costs).

It should be noted the lack of metrics such as customer satisfaction and employee satisfaction as well as environmental metrics. As a result, a new approach to BSC was created in the form of Green BSC. There are at least two ways in which green measures can be incorporated into BSC: as an added new environmental perspective (along with the four existing ones) or as a part of the well-known perspectives ${ }^{23}$.

Adding an additional perspective to the BSC may is the simplest approach. This is often a sustainability perspective made up not only with environmental performance indicators but also social ones. But ideally, green measures should be incorporated into traditional BSC perspectives. Cause and-effect linkages between strategies and greening efforts can be seen then.

SCOR reference model combines three concepts: business process reengineering (BPR), benchmarking and best practices. SCOR helps companies to increase efficiency of supply chains by analyzing competition and properly configuring their chains. It helps to explain the processes in the entire supply chain and provides a basis for processes' improvement. It encompasses major processes on a macro-level and then their decomposition: plan, source, make, deliver, return. The fact of adding the last process of reverse logistics can be perceived as a result of growing importance of green aspects. But the recent developments and growing interest in the issue of greening of supply chains has also led (as in the case of BSC) to development of the so called Green SCOR. It integrates best environmental practices and metrics into one planning process which should be easily understood and accepted. Green SCOR includes: industry best practices for making supply chains more environment friendly, metrics focusing on measurement of greening results, as well as processes to address waste management. It also helps to explain the processes along the entire supply chain and provides a basis for how to improve those processes. The metrics in the model were designed to address the environmental impacts associated with each process element. Metrics that captured environmental improvements but did not

${ }^{22}$ F. Zhao, Maximize Business Profits through E-partnerships, IDEA Group Publishing, Hershey, USA 2006, p. 210.

${ }^{23}$ G.P. Kurien, M.N. Qureshi, Performance measurement systems for green supply chains using modified balanced score card and analytical hierarchical process, Scientific Research and Essays, Vol. 7(36), 13 September, 2012, pp. 3149-3161. 
lead to supply chain improvement along at least one of the performance attributes were not included.

The following benefits of GreenSCOR's adoption should appear: improved environmental management performance, improved supply chain management performance as well as improved green supply chain initiatives. Using SCOR allows possible identification of environmental aspects and impacts (which are often hidden). The GreenSCOR elements can help in development of best practices that can mitigate those impacts. Hence green performance can be improved $^{24}$.

To effectively assess the supply chain performance, the three major sustainable activities must be taken into consideration: trying to make quantitative goals in accordance with budget, establishing of objectives in accordance with main objective of an enterprise, setting the mechanism of follow-up evaluation process to monitor the performance ${ }^{25}$. The above presented ways of performance assessment seem to meet these criteria.

\section{Conclusions}

Many firms do not maximize their supply chain's potential because they neglect development of performance measures and metrics indispensable for real integration. Chan states that performance measurement systems describe the feedback on activities with respect to meeting strategic objectives of the company or its supply chain. It should reflect the need for improvement for areas with the performance which is below the expected one ${ }^{26}$.

The goals of the performance measurement system of the green supply chain must be directed towards: identification of green goals for the chain, optimum functioning of the entire chain and individual companies, early identification of failures, systematic search for weak points and their causes, clear measurement of the results achieved by the participants, and continuous help in fulfilling routine tasks.

${ }^{24} \mathrm{http}: / /$ postconflict.unep.ch/humanitarianaction/documents/02_08-04_05-11.pdf

${ }_{25}$ A.M. Jolly-Desodt, Benchmarking of the textile garment supply Chain using the SCOR model, International conference on service systems and service management. Troyes of France, V3, 2006, pp. 1427-1432.

${ }^{26}$ F.T.S. Chan, Performance measurement in a supply chain, International Journal of Advanced Manufacturing Technology, 21, 2003, pp. 534-554. 


\section{Bibliography}

Ackermann I., Using the balanced scorecard for supply chain management: Prerequisites, integration issues, and performance measures, [in:] Strategy and organization in supply chains, ed. S. Seuring, M. Muller, M. Goldbach, U. Schneidewind, Physica-Verlag, New York 2003, pp. 289-304.

Andic E., Yurt O., Baltacioglu T., Green supply chains: efforts and potential applications for the Turkish market. Resources, Conservation and Recycling 58, 2012, pp. 50-68.

Bhattacharya A., Mohapatra P., Kumar V., Dey P.K., Brady M., Kumar M., Nudurupati T., Sai S., Green supply chain performance measurement using fuzzy ANP-based balanced scorecard: a collaborative decision-making approach, Production Planning \& Control, 25 (8), 2014, pp. 698-714.

Bullinger H.J., Küchner M., van Hoof A., Analysing supply chain performance using a balanced measurement method, International Journal of Production Research 2002, Vol. 40, No. 15, p. 3539 .

Cai J., Liu X., Xiao Z., Liu J., Improving supply chain performance management: A systematic approach to analyzing iterative KPI accomplishment, Decision Support Systems, 46, 2009, pp. 512-521.

Chan F.T.S., Performance measurement in a supply chain, International Journal of Advanced Manufacturing Technology, 21, 2003, pp. 534-548.

Dura P., Mierniki procesów logistycznych, Gospodarka Materiałowa i Logistyka, 3/2002, pp. 2-3.

Estampe D., Lamouri S., Paris J.-L., Brahim-Djelloul S., A framework for analysing supply chain performance evaluation models, International Journal of Production Economics, Vol. 142, No. 2, 2013, pp. 247-258.

Handfield R.B., Walton S.V., Seegers L.K., Melnyk S.A., 'Green'value chain practices in the furniture industry, Journal of Operations Management, 15 (4), 1997, pp. 293-315.

Handfield R.B., Straube F., Pfohl H.-Ch., Trends and Strategies in Logistics and Supply Chain Management: Embracing Global Logistics Complexity to Drive Market Advantage, Hamburg 2013.

Hassini E., Surti C., Searcy C., A literature review and a case study of sustainable supply chains with a focus on metrics, Int. J. Production Economics 140, 2012, pp. 69-82.

Hervani A.A., Helms M.M., Sarkis J., Performance measurement for green supply chain management, Benchmarking: An International Journal 12 (4), 2005, pp. 330-353.

Jakhar S.K., Designing the Green Supply Chain Performance Optimisation Model, Global Journal of Flexible Systems Management, September 2014, 15(3), pp. 235-259.

Jolly-Desodt A.M., Benchmarking of the textile garment supply Chain using the SCOR model, International conference on service systems and service management. Troyes of France, V3, 2006, pp. 1427-1432.

Keeping Score: Measuring the Business Value of Logistics in the Supply Chain, ed. J.S. Keebler, CSC University of Tennessee, Council of Logistics Management 1999, p. 8.

Kurien G.P., Qureshi M.N., Performance measurement systems for green supply chains using modified balanced score card and analytical hierarchical process, Scientific Research and Essays, Vol. 7(36), 13 September, 2012, pp. 3149-3161.

Mandal S., Supply Chain Performance: Review of Empirical Literature, Romanian Review of Social Sciences, No. 3, 2012, pp. 26-27.

Min S., Roath A.S., Daugherty P.J., Genchev S.E., Chen H., Arndt A.D., Richey R.G., Supply chain collaboration: what's happening?, The International Journal of Logistics Management, Vol. 16, No. 2, 2005, s. 239. 